\title{
Contagion in Turkish Stock Market: Evidences from Developed and Emerging Markets
}

\author{
Elif Hilal NAZLIOĞLU1, Dündar KÖK²ْ
}

\begin{abstract}
The aim of this paper is to empirically investigate financial contagion between developed and emerging markets and Turkish stock market. With this purpose, daily closing values of Turkish (BIST100), US (SPX), German (DAX), Brazilian (IBOV), Russian (RTSI), Indian (NIFTY), Chinese (SHCOMP) market indexes for the period 04.01.2000-12.11.2019 have been used in cointegration and causality analyses, where the latter takes into account structural breaks endogenously. While findings of co-integration analysis demonstrate tendency of Turkish stock market to move together with developed markets SPX and DAX, and with NIFTY from among emerging ones, allowing for structural breaks has been found significant in terms of methodological perspective. Findings from causality analysis, on the other hand, indicate presence of various causality relations among markets, including unilateral relations from SPX and DAX to BIST100, bilateral relations of BIST100 with IBOV and NIFTY, and unilateral ones of RTSI and SHCOMP with BIST100 index. Our analyses in general point out contagion to Turkish market from both developed markets and Russia and China from among emerging markets, moreover mutual interdependence between Turkey and the emerging markets of Brazil and India.
\end{abstract}

Keywords: contagion, financial crisis, co-integration with structural breaks, emerging stock markets

Jel Codes: F36, G15, G01, C22

\section{Introduction}

The spreading nature of the adverse effects of crisis-induced shocks to other countries during post-crisis period, which are influential on investor behaviours, financial and macroeconomic stability in relation to increased capital flows fostered by financial liberalization and globalization, has led to expansion in research towards financial contagion, particularly after 2008 Financial Crisis. Indeed, there is broad opinion in literature which suggests that besides 2008 Financial Crisis, the common feature of crises which broke out in 1990s, i.e. North European crisis of 1992, Mexican crisis in 1994, 1997 crisis in Asia, followed by the one in Russia in 1998 , is contagion.

Factors such as concentration and level of economic relations between countries, affiliations through unions and similar bodies and geographical proximity are likely to affect levels of exposure to crises and portfolio outcomes through diversification in different dimensions, though in comparable scales. Brazil, Russia,
India, and China (collectively BRIC), which are among emerging economies, are similar countries in terms of rapid growth, booming domestic demand, attracting foreign investments and low per capita income. Shocks arising from geopolitical concerns and economic uncertainties could cause changes in directions of foreign capital flows, and comparable structural breaks in the economies of these countries.

Analysis of contagion for Turkey, which is one of the emerging market economies and possesses similar financial and economic structure as BRIC countries, also turns out to be important for pinpointing both pre-emptive indicators concerning financial deepening and macroeconomic stability, and diversification opportunities available to individual investors. In this regard, this paper aims at investigating existence of contagion within the interactions of Turkish stock market with international financial markets. Taking US SPX and German DAX indexes as proxies for developed markets, and Brazilian (IBOV), Russian (RTSI), Indian 
(NIFTY) and Chinese (SHCOMP) stock market indexes, i.e. leading indexes of BRIC countries, for emerging countries as sample set, we implement correlation, co-integration and causality analyses for pre-crisis (04.01.2000-21.02.2007) and post-crisis (22.02.200712.11.2019) periods, and also the extended versions of the latter two analyses, which take structural breaks into account, on the whole period. This study hence aims to investigate the contagion phenomenon in Turkish stock markets by conducting a comprehensive analysis. We first employ the conventional co-integration tests which does not account for structural breaks. We then proceed with the co-integration testing with structural breaks since ignoring breaks may results in a false conclusion in favour of co-integration. We next consider causal linkages between the stock markets by using the Toda and Yamamoto approach to causality and a recent extension of considering smooth shift in causality framework. The previous works on Turkey do not consider the issue of structural breaks in a systematic framework based on a multiple testing strategy.

The correlation analysis on price series points out high increases in correlation coefficients in post-crisis period with respect to their pre-crisis levels. While the co-integration analysis which ignores structural breaks provides evidences for co-integration relations between Turkey and Brazil, India and Germany in the pre-crisis period, and also those between Turkey with Germany, and Turkey with India after crisis, the co-integration analysis allowing for structural breaks which is performed for the whole period exhibits that co-integration relationship between Turkey and developed economies, i.e. US and Germany, unfolds in case regime and trend changes are accounted for. These findings are consistent with those of Celik (2012), Islam et al. (2013), Bekiros (2014), Ayaydin (2014), Kocabas (2016), Kirac \& Cicek (2017) and Gulzar et al. (2019) in literature. On the other hand, we determine through causality analysis, which disregards structural breaks, that US and German indexes provide forecast information for Turkish index, and there is feedback relation between Turkey and BRIC markets except Russian market. This end is in conformity with studies of Var (2015) and Atakan et al. (2010).

For investigating causal linkages, we first benefit from the Toda and Yamamoto (1995) approach to Granger causality. Incorporating structural breaks in causality analysis may be crucial due to the well-known fact that financial markets, particularly in emerging markets, are subject to structural changes. From the point of statistical inference, the null of non-causality can be rejected even though there is no causality when data generating process has structural shifts (see, Ventosa-Santaularia and Vera-Valdés, 2008). Monte Carlo simulations by Enders and Jones (2016) indicate that ignoring structural breaks in a VAR model leads Granger causality test to be biased towards a false rejection of the true null hypothesis. The simulation evidence further reveals that unless breaks are properly modelled, Granger causality tests also tend to have an over-rejection of the null hypothesis. These findings not only indicate the importance of accounting for any structural shifts but also necessitate a careful treatment of how breaks are captured (Nazlioglu et al., 2016). In order to control for structural breaks, we employ the causality analysis which takes structural shifts into account suggested by Nazlioglu et al. (2016) which employ a Fourier approximation in the Toda and Yamamoto approach to account for gradual breaks in Granger causality analysis. The causality analysis which incorporates possible structural breaks puts forth contagion effects to Turkey both from developed countries (i.e. US and Germany) and from Russia and China among emerging ones; additionally feedback relations between Turkey with Brazil and China for the total period covered. We report importance of structural breaks in analysis of financial contagion since we find that these affect the direction of causality to a great extent for Chinese and Russian cases.

\section{Literature Review}

Literature concerning financial contagion can basically be explored though three main lenses. Whereas fundamental view focuses on real markets, financial and coordination views oversee financial markets and macroeconomic policy implications respectively (Rigobon, 2016). Based on financial contagion conceptualization and its empirical setup, this paper traces signs of contagion in developed and emerging markets by focusing on the financial view among the three lenses. Forbes \& Rigobon (2002) assert that existence of contagion can be verified in terms of significant increase in interaction with markets of other countries following a financial shock. In addition, some finer distinctions within the theoretical definition of contagion evolve, on the basis of determining channels of international shock transmissions, through increased probability of crisis in one country depending on one that occurs in another; spread of volatility of asset prices to other countries from the country where crisis has taken place; significant increases in co-movements of prices and 
volumes between markets and finally change in concentration in transmission channel further to a shock Pericoli \& Sbracia (2003).

Empirical literature related with contagion has been expanding, and we summarize some research papers in Table A.1. In studies on 2008 Economic Crisis and its effects, the general finding concerning financial contagion suggests consequences on different economies at varying degrees. The findings of Samarakoon (2011)'s research on dependency and contagion between US and foreign markets with a broad sample of 22 emerging and 40 frontier markets covering 2000-2009 indicate that dependency is due to financial shocks in US markets while contagion effects are originated from those observed in emerging markets. Findings concerning dependency supports Forbes \& Rigobon (2002)'s view in that strong linkages in crisis do not result in contagion provided that they remain at high levels prior to crisis and such linkages which do not scale up compared to stable (normal) period can neither be accounted for contagion, hence these circumstances can be explained by interdependence. Moreover, the paper suggests interdependence is valid for frontier markets, and that shocks in US has contagion effects towards them. In a similar research on interdependence, Dimitriou et al. (2013) have investigated contagion effects due to global financial crisis for BRICS and US stock markets in 1997-2012. Findings show that there is no contagion effect for most BRICS countries in early stages of crisis and that relations have been recoupled after collapse of Lehman Brothers. Furthermore, starting from 2009, increased correlations between BRICS and US markets have been reported, in consequence compared to bear markets, higher interdependence is inferred in bull markets. These findings also suggest lack of clear contagion pattern for all BRICS countries. The authors have explained this end by the existence of mutual trade and financial structures among countries involved. In another study, Chancharoenchai \& Dibooglu (2006) have examined contagion and spill-over effects of 1997 Asian crisis on six major stock markets, i.e. Thailand, Philippines, Indonesia, Malaysia, Korea, and Taiwan. Their analysis through GARCH-M Model justifies some dependence scheme in terms of volatility between developed (US and Japan) and emerging markets prior to pre-crisis period (03.01.1994-31.12.1996) and after the extended period (03.01.1994-31.12.1999). Additionally, they have found out that feedbacks between East Asian stock markets were strong before the Asian crisis and remained influential thereafter. On the other hand, in a group of studies concerning transmission mechanism in literature, findings supporting financial spill-over outweighs those for financial contagion. In a sense, this group can also be considered within interdependence framework.

Islam et al. (2013) have analysed financial contagion and volatility spill-overs between 15 select countries from Asia-Pacific and Europe with a dataset of weekly periodicity covering 1997-2013. Their findings evidence volatility spill-over for the largest eight economies (India, Japan, China, South Korea, Taiwan, Malaysia, Singapore and Australia) in Asia-Pacific, and financial contagion for European markets (Austria, France, Germany, Greece, Holland, Italy and UK) due to overwhelming cross-volatility transmissions. In a similar study, Polat (2018) reports highest financial risk transmission between US and UK, and those at high levels between Germany, France, and Italy. While these countries' membership in EU is highlighted, Turkey is identified with the lowest financial risk transmission. It is apparent that volatility, which is the subject matter of both studies, is affected significantly from level of interdependence between major economies. On the other hand, Roy \& Sinha Roy (2017) have studied multi-directional volatility transmission in asset markets in order to measure the extent of financial contagion specifically in Indian markets. Their analysis is based on daily returns of commodity derivative indexes and other assets for the period 2006-2016. The authors determine that the highest and lowest degree of contagion for commodity derivatives are with the stock market and gold market respectively and that commodity and stock markets are volatility transmitters whereas bond, FX and gold markets are volatility receivers in net terms, hence volatility is transmitted to commodity markets via stock markets only. As a matter of time-varying feature of such volatility transmission, higher values are detected for Global Financial Crisis and great Rupi depreciation of 2013-2014.

Var (2015) has studied financial contagion specifically for Turkey taking data for US, Brazilian, Indian, Hong Kong, UK, Japanese, Mexican, and Russian stock markets covering 2009-2014. According to results, volatilities on all these markets influence Turkish market's volatility, moreover asymmetries in transmission towards Turkish market have been reported from all except Indian and Japanese markets. Results of Granger causality analysis show that Indian, Brazilian, and Russian stock market returns are Granger cause of Turkish stock market returns. Those for variance decomposition indicate Turkish market returns are affected by their 
own lagged values to a great extent and by US market most among the foreign markets. Impulse-response functions, on the other hand, show that Turkish market reacts to shocks in US and UK markets most, and additionally shocks in Brazilian, Russian, and Indian stock markets are reported to impact Turkish market returns.

There are also studies centred on financial contagion rather than financial transmission in explaining interactions among markets in the literature we focus on. Bekiros (2014) has analysed contagion and spill-over effects of US financial crisis on BRIC countries during periods of Global Financial Crisis and Debt Crisis of Euro area. The empirical findings over American, German, Brazilian, Russian, Indian, and Chinese stock market indexes for 1999-2011 indicate increased integration of BRIC markets to international markets, hence presence of contagion effects. Similarly, Gulzar et al. (2019) have examined transmitted effects of Global Financial Crisis on emerging Asian financial markets (India, China, Pakistan, Malaysia, Russia and Korea) for the period 20052015, by distinguishing three subperiods, i.e. pre-crisis, crisis, post-crisis periods. The authors have found that detected long-term co-integration relationship of emerging markets has continued with an increase further to crisis and a shock in US financial markets has only short-term effects on returns in emerging markets. Celik (2012), in a similar set up have reported results confirming financial contagion effects between various emerging market economies and FX markets of developed countries during American High-risk Loan Crisis (2005-2009) after having found supporting evidence for most countries in the sample, i.e. Australia, Brazil, Canada, China, Denmark, India, Japan, Malaysia, Mexico, New Zealand, Norway, Singapore, South Africa, South Korea, Sweden, Switzerland, Taiwan, Thailand, Turkey and US. This paper also stresses that contagion has more effects on emerging markets. Baur (2012)'s research, on the other hand distinctively focuses on financial contagion effects on various sectors. Tracing the transition of Global Financial Crisis of 2007-2009 into real economies through 10 sectors in 25 leading developed and emerging markets for the period 19792009, the paper reports findings evidencing strong contagious linkages between Global Financial Crisis and financial sector stocks and stock markets in general.

As for the research papers centred on Turkey, Alper \& Yilmaz (2004) is among the earliest studies supporting presence of financial contagion. They report contagious effects to volatility on real returns of Turkish stock market from both developed markets, i.e. finance centres like US, UK and Hong Kong and emerging markets like Brazil, South Korea, and Russia. Similarly, Atakan et al. (2010), Ayaydin (2014), Kocabas (2016), Kirac \& Cicek (2017), Altan \& Yildirim (2019) and Akcali et al. (2019) have affirmed contagion for Turkey for different periods, channels, and cases. As pointed out recently by Buberkoku \& Kizildere (2018), the contagion channel of 2007-2008 Global Financial Crisis to Turkish financial markets is the stock market rather than FX and interest markets.

\section{Econometric Methodology}

\subsection{Testing for Co-integration}

For analyzing the long-run relationship between Turkish and the selected stock markets, we conduct the co-integration analysis. A co-integration regression model can be written as

$$
y_{t}=\alpha+\beta X_{t}+\epsilon_{t}
$$

or

$$
y_{t}=\alpha+b t+\beta X_{t}+\epsilon_{t}
$$

where $t=1, \ldots, T, y_{t}$ represents the Turkish stock market, $x_{t}$ denotes each of the selected foreign stock markets, $\alpha$ is the intercept term, $b$ is the trend coefficient, $\beta$ is the co-integration parameter, and $\epsilon_{t}$ is the error term. Engle \& Granger (1987) propose a simple co-integration test based on conducting augmented Dickey-Fuller (ADF) unit root test of Dickey \& Fuller (1979) on the residuals $\widehat{\epsilon_{t}}$. Phillips \& Ouliaris (1990) use the same idea by conducting the $Z_{\alpha}$ and $Z_{t}$ unit root tests of Phillips \& Perron (1988) on the residuals. If the residuals are stationary, there is co-integration relationship between $x_{t}$ and $y_{t}$.

As outlined earlier, we conduct the co-integration analysis for the total and the pre-crisis and post-crisis periods in order to investigate whether a possible co-integration relation differs across the periods. To this end, we divide the data into the pre-crisis and the post-crisis periods by considering the Global Financial Crisis as a major breakpoint. Nonetheless, determining the break date a priori to split data into the sub-periods is difficult in practice and hence is a challenge for practitioners. Gregory \& Hansen $(1996 a, b)$ determine a structural break endogenously in a co-integration relation and therefore allow us to test for the existence of co-integration with a structural break. Authors extend the co-integration regressions in Equations (1a) and (1b) with a structural break. They define the level 
shift model, the regime shift model and the regime and trend shift model. The level shift model is given as

$$
y_{t}=\alpha_{1}+\alpha_{2} D_{t}+\beta X_{t}+\epsilon_{t}
$$

and the regime shift model is given as

$$
y_{t}=\alpha_{1}+\alpha_{2} D_{t}+\beta_{1} X_{t}+\beta_{2}\left(X_{t} D_{t}\right)+\epsilon_{t}
$$

and finally, the regime and trend shift model is given

$$
\begin{aligned}
& y_{t}=\alpha_{1}+\alpha_{2} D_{t}+b_{1} t+b_{2}\left(t D_{t}\right)+ \\
& \beta_{1} X_{t}+\beta_{2}\left(X_{t} D_{t}\right)+\epsilon_{t}
\end{aligned}
$$

where $D_{t}=$ if $t>T_{b}$ and $D_{t}=0$ otherwise, that $T_{b}$ is the break time. We estimate the model for each regime shift $T_{b} \in T$, and apply then unit root test to the residuals. Gregory \& Hansen (1996a) hence propose the extensions of the Engle \& Granger (1987) ADF, the Phillips \& Ouliaris (1990) $Z_{\alpha}$ and $Z_{t}$ tests for co-integration by allowing structural break(s). The co-integration tests with a structural break denoted as $A D F^{*}, Z_{\alpha,}^{*}$ and $Z_{t}^{*}$ are the smallest value of $A D F, Z_{\alpha}$ and $Z_{t}$ tests corresponds to all possible break points.

\subsection{Testing for Causality}

Granger (1969) causality analysis is based on VAR(p) model, defined as

$$
y_{t}=\gamma+\Phi_{1} y_{t-1}+\cdots+\Phi_{p} y_{t-p}+u_{t}
$$

where $y_{t}$ consists of $m$ endogenous variables, $\gamma$ is the constant terms, $\Phi=\left(\Phi_{1}, \ldots, \Phi_{p}\right)^{\prime}$ are autoregressive parameters and $u_{t}$ are the residuals with a white-noise process. Here, $y_{t}$ includes Turkish and a foreign stock market prices, and $\operatorname{VAR}(p)$ is a bivariate model. Since the distribution of Wald test asymptotical depends on unit root and co-integration properties of the variables, Toda and Yamamoto (1995) suggest estimating the lag-augmented VAR model by using the level variables. In Toda \& Yamamoto (TY) approach a VAR $(p+d)$ model is defined, given by

$$
\mathrm{y}_{\mathrm{t}}=\gamma+\Phi_{1} \mathrm{y}_{\mathrm{t}-1}+\cdots+\Phi_{\mathrm{p}+\mathrm{d}} \mathrm{y}_{\mathrm{t}-(\mathrm{p}+\mathrm{d})}+\mathrm{u}_{\mathrm{t}}
$$

where $d$ is the maximum unit root degree of variables. The null hypothesis of Granger non-causality is defined as $H_{o}: \Phi_{1}=\cdots=\Phi_{p}=0$ for $m^{\text {th }}$ element of $y_{t}$ and Wald statistic has an chi-square distribution with $p$ degrees of freedom. In some recent studies, it is shown that the bootstrap distribution leads to more powerful test statistic in small samples and is not affected from unit root and co-integration (among other, Balcilar et al., 2010). We therefore also use the bootstrap distribution of Wald statistic ${ }^{3}$.

As in the co-integration analysis, we conduct the causality analysis for the total and the pre-crisis and post-crisis periods in order to investigate whether a possible co-integration relation differs across the periods. Besides, we also employ the causality analysis which takes structural shifts into account suggested by Nazlioglu et al. (2016) which employ a Fourier approximation in the TY approach to account for gradual breaks in Granger causality analysis. Their approach is known as the Fourier TY test that is defined as

$$
\mathrm{y}_{\mathrm{t}}=\gamma(\mathrm{t})+\Phi_{1} \mathrm{y}_{\mathrm{t}-1}+\cdots+\Phi_{\mathrm{p}+\mathrm{d}} \mathrm{y}_{\mathrm{t}-(\mathrm{p}+\mathrm{d})}+\mathrm{u}_{\mathrm{t}}
$$

where the constant $\gamma(t)$ depends on time and has hence structural shifts in $y_{t}$. Fourier approximation models gradual structural shifts, defined as

$$
\gamma(t)=\gamma_{0}+\gamma_{1} \sin \left(\frac{2 \pi k t}{T}\right)+\gamma_{2} \cos \left(\frac{2 \pi k t}{T}\right)
$$

where $k$ is the Fourier frequency. Substituting Eqn. (6) into Eqn. (2) yields

$$
\begin{aligned}
& \mathrm{y}_{\mathrm{t}}=\gamma_{0}+\gamma_{1} \sin \left(\frac{2 \pi k \mathrm{kt}}{\mathrm{T}}\right)+\gamma_{2} \cos \left(\frac{2 \pi k \mathrm{t}}{\mathrm{T}}\right)+ \\
& \Phi_{1} \mathrm{y}_{\mathrm{t}-1}+\cdots+\Phi_{\mathrm{p}+\mathrm{d}} \mathrm{y}_{\mathrm{t}-(\mathrm{p}+\mathrm{d})}+\mathrm{u}_{\mathrm{t}}
\end{aligned}
$$

Eqn. (7) necessitates to determine the Fourier frequency $k$ and lag length $p$. Following Nazlioglu et al. (2016), we determine optimal frequency and lags by Schwarz information criterion.

\section{Data}

We take SPX and DAX indexes to represent the developed markets since US and Germany are the most important trade partners of Turkey. IBOV, RTSI, NIFTY and SHCOMP stock indexes of BRIC (Brazil, Russia, India, and China) countries make up the sample set for the emerging markets. These indicative indexes are all chosen since we believe they portray best the strength of economies and deepness of financial markets they are related. Moreover, overall level of exposure to crisis can be deduced from their trends. The dataset includes 5181 daily closing prices of listed indexes obtained from

\footnotetext{
${ }^{3}$ To save space, we do not provide details of the bootstrapping method here and refer to Balcilar et al. (2010).
} 
Bloomberg database and covers the period 04.01.200012.11.2019.

In order to assess the effects of crisis better, the whole period is split into subperiods in empirical papers. Following this practice, we conduct our analysis for the whole period (04.01.2000-12.11.2019), and additionally for the two subperiods, i.e. pre-crisis period (04.01.2000-21.02.2007) and post-crisis period (22.02.2007-12.11.2019). In determining sub-periods, we adopt Bekiros (2014)'s view, which takes 22.07.2007 as a break point of crisis. The largest loss ever reported in regard to sub-prime loans, amounting to 10.5 million USD by HSBC, was declared on this day (Bekiros, 2014).

\section{Empirical Findings}

Figures 1 and 2 show the dynamics of price and return series respectively. Downward trend on all indexes after the outbreak of 2008 Financial Crisis is remarkable. Moreover, indexes are observed to rise after crisis becomes ineffective. The important point suggested by the dynamics of return series (Figure 2) is that 2008 Economic Crisis have resulted in increased volatility and overall mean in return series.
Descriptive statistics for price and return series are presented in Table 1. In general, increase in standard deviations compared to pre-crisis period implies increased volatility after crisis. Moreover, sudden drops in means are observed for post-crisis period. Skewness and kurtosis values indicate overall departure from normality. We notice that means and standard deviations of price series, except for Russia, are higher in post-crisis period compared to their pre-crisis values. This end can be interpreted as an indicator for increased price volatilities after the crisis.

The correlation matrix reported in Table 2 indicates positive correlations between markets in general. Significant increases in these after crisis when compared to those in pre-crisis period are also noticeable. Correlation coefficients have at least doubled in post-crisis period, indicating contagion among markets. Dimitriou et al. (2013) argue that there was no contagion effects for BRICS countries in the early stages of crisis, yet relations were recoupled further to failure of Lehman Brothers, and conclude that correlations between BRICS countries and US have increased since 2009. Their findings do not suggest contagion for all BRICS countries, and this end is justified by joint trade and financial setup of countries.
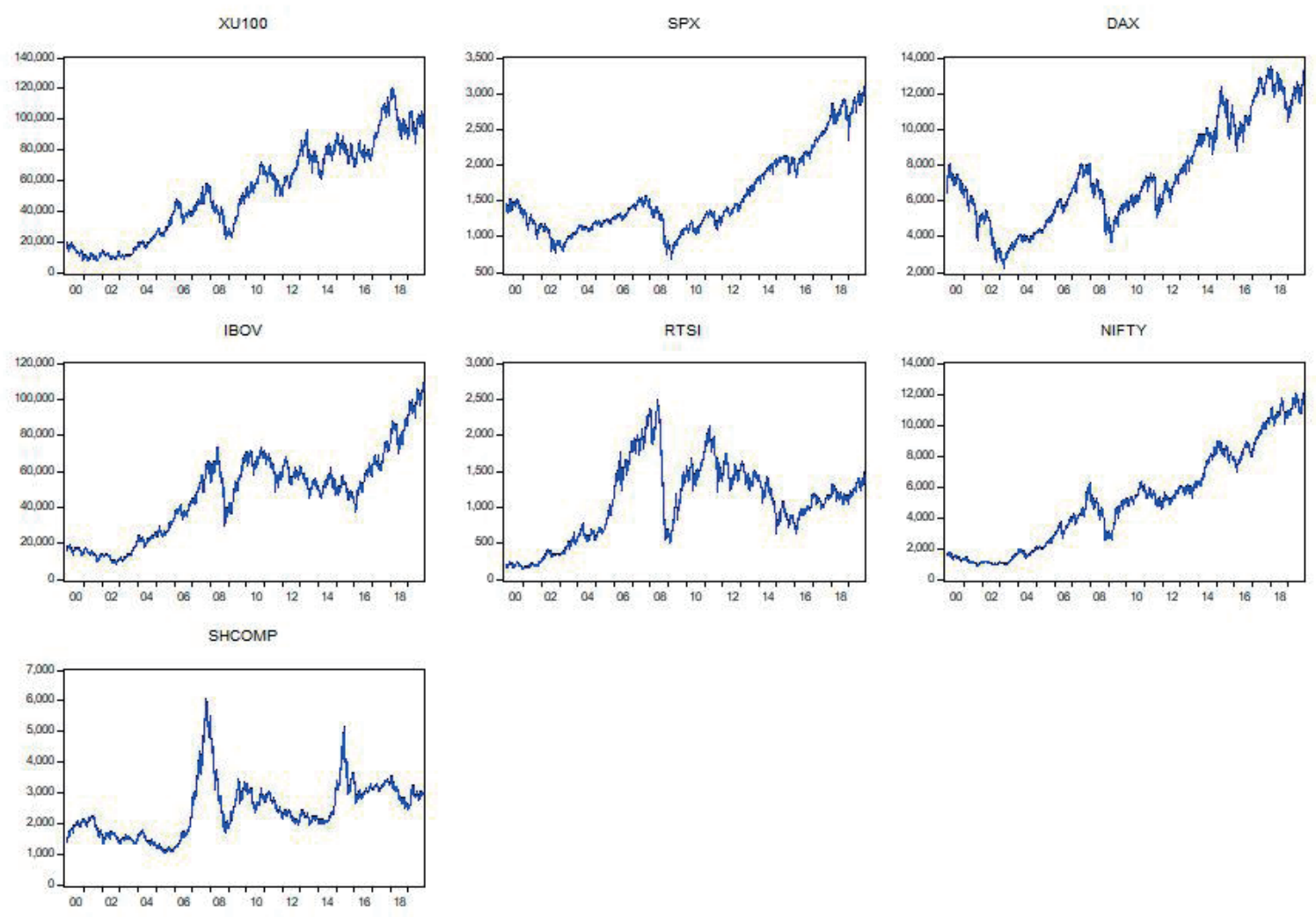

Figure 1: Price Series 
Chinese market shows mostly lower correlations, hence no connectedness with other markets. Having the least relation with other markets, China has negative relations with US and Germany before crisis, yet these turned out to be positive in post-crisis period. The change of correlations between developed countries and China in the positive direction before and after the crisis can be explained by common trade and financial frames of China with US and Germany rather than contagion effects as argued by Dimitriou et al. (2013). The high positive correlations of SPX with both DAX and IBOV before crisis are observed to hold up with some increases in the post-crisis period. Correlations of BIST100 with SPX, DAX, NIFTY and SHCOMP in post-crisis period have indeed climbed to approximately 3.5, 2.5, 2.5 and 6 times of their pre-crisis values, respectively. While this finding can be evaluated on the notion which implies positive high correlation increases the probability of systematic risk exposure, it can be interpreted as argued by Forbes \& Rigobon (2002) as well. According to this view, the persistence and even increases in positive correlations of pre-crisis period in the post-crisis period can be explained by interdependence.

The first step of co-integration analysis is to examine the unit root properties of the variables, because the co-integration tests outlined earlier are assumes that that and are integrated at order one. This means that one can proceed with testing for the existence of the long-run co-integration relationship, if the series are not stationary in the levels and are stationary in the first differences. Furthermore, the TY method also requires to determine maximum unit root degree (d) of the series. The visual examination, descriptive statistics and correlation analysis of the data are likely to signal that the stock market prices experienced structural shift(s), particularly during the 2008 Financial Turmoil. We therefore concentrate on the unit root tests that take such changes into account. In that respect, we conduct Dickey \& Fuller (1979) augmented Dickey \& Fuller (ADF) test, Zivot \& Andrews (1992) test with a break (ZA-ADF), and Enders \& Lee (2012) test with a Fourier approximation (F-ADF) ${ }^{4}$. The results from the unit root tests are reported in Table 3. For the level
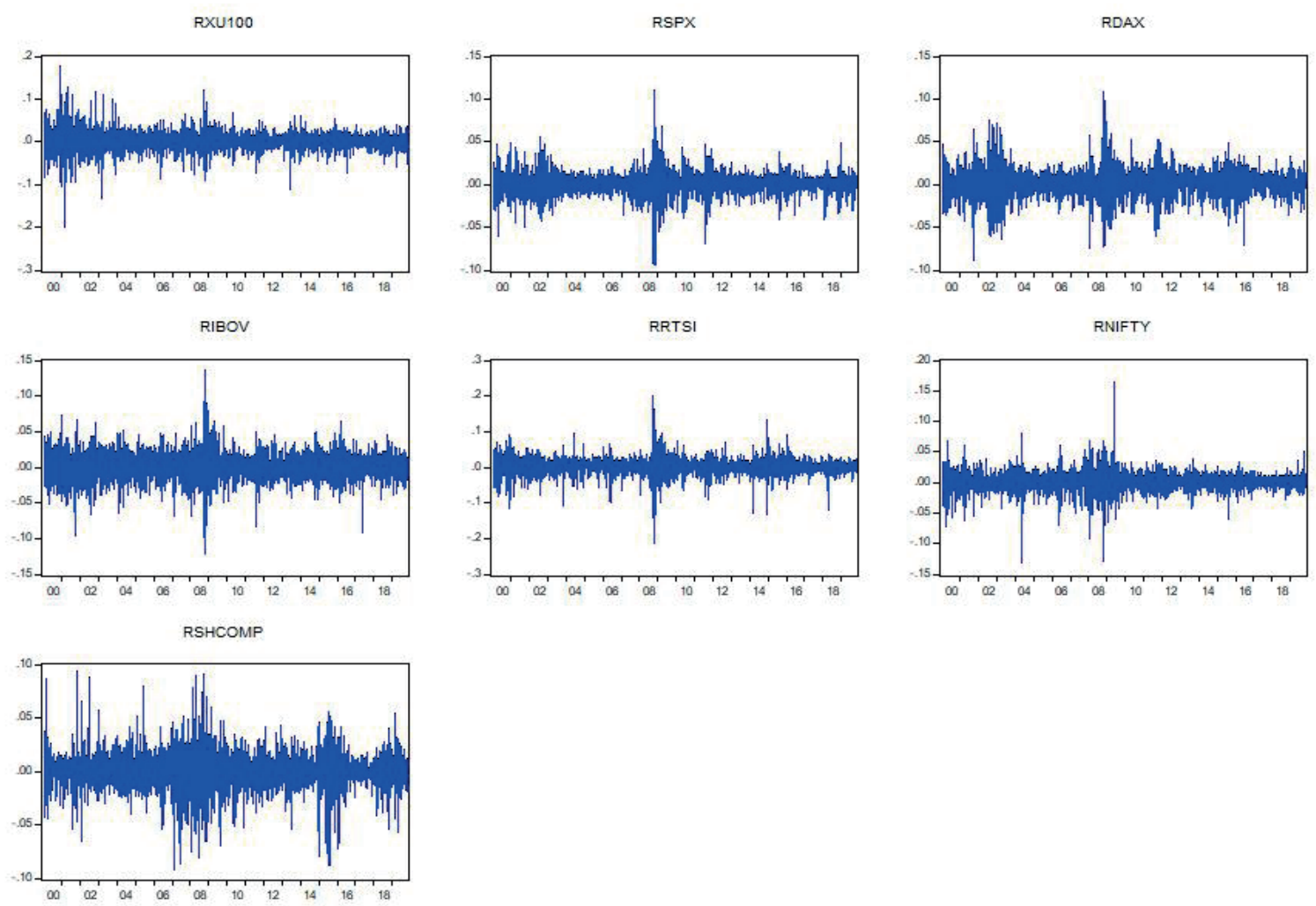

Figure 2: Return Series

\footnotetext{
${ }^{4}$ For the details of these test, we refer to the cited articles. We use GAUSS tspdlib of Nazlioglu (2019) to conduct Zivot and Andrews (1992) and Enders and Lee (2012) unit root tests.
} 
log-prices, all the tests cannot reject the null hypothesis of unit root irrespective of whether the model includes constant or constant and trend. For the first differenced prices (i.e. returns), all the unit root tests reject the null of unit root at 1 percent level of significance hence strongly support the evidence on stationarity for the stock markets returns. The estimated break dates from the Zivot and Andrews procedure indicate that the time of structural breaks do not seem to be same for each stock market. This result in fact is expected due to the fact that a response of one market can be different from another market because of investor behaviours.

Given the existence of a unit root in the level log-prices, we proceed with the co-integration analysis. To this end, we first conduct Engle \& Granger (1987) and Phillips \& Ouliaris (1990) co-integration tests for the total, the pre-crisis and the post-crisis periods. The results for the total period in the Panel A of Table 4 indicate that even though the co-integration tests for the mode with constant provides an evidence on the existence of the long-run co-integration relationship only between Turkish and Indian stock markets, the test for the model with constant and trend support a strong co-integration nexus between Turkish and both the developed and emerging economies stock markets.

As Perron (1989) points out, ignoring the possible effects of structural breaks can lead to a false rejection of the null hypothesis. At first glance, the co-integration relationship between the Turkish and the selected stock markets are slightly different from those for the total period. The results for the pre-crisis period in the Panel $B$ show that there is a co-integration relationship for Turkey with Brazil, India, and Germany at least 10 percent level for the model with constant. In the post crisis-period, we find evidence on the co-integration relationship between Turkey and Germany and between Turkey and India. However, the inclusion of a deterministic trend in a co-integration relation leads to changes in the results for both the pre- and post-crisis periods. Even though an eye look at the Turkish stock market prices in Figure 1 might signal an existence of deterministic trend in the pre-crisis period, there is not any such clear evidence in the pre-crisis period.

As discussed in Gregory \& Hansen (1996a), the breaks may cause a level or regime shift in a co-integration relation and splitting the data into sub-samples may not able to capture such dynamics. Furthermore, it is difficult to know the break date a priori to split data in practice. We hence further employ the co-integration tests with a break proposed by Gregory \&
Hansen $(1996 a, b)$ that determine a structural break endogenously in a co-integration relation. The results in Table 5 indicate an evidence on the prevalence of the co-integration relationship between Turkey and India. The results also shed light on the evidence of a co-integration relationship between Turkey and the developed economies (USA and Germany) stock market prices when we consider a regime and trend shift in the co-integration relation.

As it is discussed earlier, the contagion phenomenon implies co-movement between stock markets. Our co-integration analysis first indicates that taking the structural breaks into account in the co-integration relations between Turkey and the developed and the BRICS countries play an important role to detect the existence of the long-run co-movements. It second supports an evidence of the contagion from the developed stock markets as well as from India. These relations hence imply that international investors can make a portfolio diversification between Turkey and BRICS countries except India.

Results from Toda \& Yamamoto causality test are presented in Table 6. According to these, we obtain oneway causality relationships to Turkish stock market from US and Germany, and two-way causality relationships between Turkey, Brazil and India when structural breaks are not considered. Briefly, two types of causality relations are present, a unidirectional one from developed countries to Turkey, and a bidirectional one between BRIC countries, excluding Russia, and Turkey. Whereas one-way causality relations from developed countries to Turkey bring contagion outcomes into mind, the feedback relations Turkey has with Brazil, India and China can be justified by interdependence, which is substantiated within the context of mutual trade and financial infrastructures. As a matter of fact, Brazil, Russia, India, and China, which are among emerging economies, are similar countries in terms of their rapid growth potential, booming domestic demand, attractive foreign investment environment, and additionally low per capita income. Shocks triggered by countries' geopolitical positions and conditions marked by economic uncertainties can result in sudden changes in the direction of foreign capital flows to these countries and similar structural breaks in their economies. From this point of view, such an interdependence relationship for Turkey, which is among the emerging economies with compatible financial and economic structure as BRIC countries, comes out to be significant for both determining leading indicators related to financial 
deepening and macroeconomic stability, and portfolio diversification facilities for individual investors.

We reach neutrality finding between Turkey and Russia, which implies lack of impact in between. Considering Turkish and Russian stock markets can mutually be considered safe heaven with one another, this finding can be regarded as a portfolio diversification opportunity for investors.

The summary of Toda \& Yamamoto causality test with a Fourier Approximation is reported in Table 2. The motivation behind selecting this methodology is its incorporation of structural breaks in the analysis and providing information on breaks in a flexible way, with no dependence on prior forecasts for number and time of possible break points. The result of the test indicates validity of one-way causality relation from US and German markets to Turkish stock market and two-way causality relation between Turkish, Brazilian and Indian markets. These findings of the analysis are in line with causality analysis which does not account for structural breaks. However, allowing for structural breaks has led to changes in findings of the causality tests of Turkey with Russian and Chinese markets. While Toda \& Yamamoto causality analysis which has no reference to breaks does not indicate any causality relation between Turkish and Russian markets, we observe one-way causality relation from Turkey to Russia through this analysis which considers such possible breaks. Similarly, one-way causality relation from Turkey to China is detected when breaks are allowed, whereas the former test attests causality relations in both ways. In consequence, we obtain one-way causality relations from developed countries to Turkey, and one-way causality relations between the emerging economies of Russia and China with Turkey, additionally two-way causality relations between Turkey, Brazil, and India.

In this respect, one-way causality relations from developed and emerging countries to Turkey, and feedback relations between Turkey and emerging markets can be explained by contagion and interdependence, respectively. Moreover, we stress the finding which indicates that the direction of causality, in case of China and Russia, is affected by breaks.

\section{Conclusion and Discussion}

The preliminary findings through descriptive statistics of this paper, which examines financial contagion phenomenon between Turkish stock market and developed markets of US and Germany, and also emerging markets of Brazil, Russia, India, China (BRIC) using co-integration analysis allowing for structural breaks (Engle \& Granger, 1987; Phillips \& Ouliaris, 1990; Gregory \& Hansen, 1996a) and causality analysis (Toda \& Yamamoto, 1995; Nazlioglu et al., 2019) along with correlation analysis, remark that the means and standard deviations of price series are higher in post-crisis period than before crisis for all economies apart from Russia. This outlook can be interpreted as an indication for increased price volatilities in post-crisis era. Hence, initial findings for noticeable rise in volatilities can be regarded as primary evidence for contagion in terms of the definition suggested by Forbes \& Rigobon (2002).

On the other hand, change in correlation in between developed countries in the positive direction before and after the crisis can be attributed to joint trade and financial settings of countries rather than contagion (Dimitriou et al., 2013). The correlations of SHCOMP with SPX and DAX analysed in this paper can be regarded in this vein. A similar connection which refers to the persistence of high positive correlation of SPX with DAX and IBOV before the crisis with some increase in post-crisis period has also been observed in BIST100 index with developed and other emerging economies, but with a lesser extent. Besides implying increased exposure to systematic risk jointly, high positive correlation between financial markets of countries brings interdependence phenomenon forward as highlighted by Forbes \& Rigobon (2002) and Dimitriou et al. (2013). In fact, similar characteristics of Brazil, Russia, India and China from among emerging economies with the Turkish economy, e.g. rapid growth potential, roaring domestic demand and attractiveness for foreign investors, could set ground for sudden changes in the direction of foreign capital flows in these countries and occurrence of comparable structural breaks, especially via shocks triggered by economic uncertainties. This dependence relation, as brought about here specifically for Turkey, may accommodate potential for both creating portfolio diversification for individual investors and being an economic indicator concerning financial deepening and macroeconomic stability.

With no prior practice within contagion framework and the Turkish stock market, co-integration analysis allowing for structural breaks implemented here has manifested co-integration relation between BIST100 and NIFTY for all break specifications, and those for Turkish market with the developed indexes, SPX and DAX in case of regime and trend shifts. This end can also be considered as other indications for contagion between Turkey and developed markets, and interde- 
pendence between Turkey and emerging markets. Our findings for contagion and interdependence through correlation and co-integration analyses are in parallel with those in literature (Kirac \& Cicek, 2017; Ayaydin, 2014; Islam et al., 2013; Bekiros, 2014; Gulzar et al., 2019; Celik, 2012; Kocabas, 2016) as well.

Furthermore, the causality analysis accounting for structural breaks substantiates one-way causality relations from developed market samples, SPX, and DAX, to BIST100; two-way causality relations of BIST100 with IBOV and NIFTY; and finally, one-way causality relations between RTSI and SHCOMP with BIST100 index. The common findings of correlation, co-integration and causality analyses, where the latter two take structural breaks into account, can be viewed to correspond to contagion phenomenon in terms of one-way causality relations from developed countries, US and Germany, and from emerging economies of Russia and China to Turkey; and to interdependence phenomenon in terms of two-way causality (feedback) relations of emerging economies of Brazil and India with Turkey. In this respe$\mathrm{ct}$, we conclude that possible shocks arising both from US and Germany, which are developed markets, and from Chinese and Russian emerging stock markets have high probability of contagion to Turkish stock markets.

Studies in this domain can be extended with causality approach considering volatility transmissions, and co-integration and causality approaches focusing on quartiles of distribution in the future. Moreover, empirical work is also possible to explain reasons of contagion by integrating risk factors due to geopolitical positions of countries. 


\section{References}

Akcali Yasar, B., Mollaahmetoglu, E. \& Altay, E. (2019). Contagion analysis of interest rates, inflation and exchange rate shocks in Turkey by implementing arma-egarch model, Istanbul Gelisim Universitesi Sosyal Bilimler Dergisi, Gelisim-UWE 2019 Özel sayi, 29-43.

Alper, E. C. ve K., Yilmaz. (2004). Volatility and contagion: evidence from the İstanbul stock exchange. Economic Systems. 28, 353-367.

Altan, I.M. \& Yildirim, M. (2019). Uluslararasi finansal piyasalarda bulasma etkisi, II. International Conference on Empirical and Social Sciences (ICEESS' 19), June 20-21-22, 2019. Bandirma, 452-459.

Atakan, T., Gumrah, U. \& Gokbulut Ilker, R. (2010). Contagion effects of the credit crisis in financial markets of the United States to emerging countries: an evidence from Turkey, Trakya Universitesi Sosyal Bilimler Dergisi, 12(1),388-414.

Ayaydin, H. (2014). A study on the relationship between international diversification, financial contagion, and the global financial crisis. Ataturk University Journal of Economics \& Administrative Sciences, 28 (3), 43-67.

Balcilar, M., Ozdemir, Z.A., Arslanturk, Y. (2010). Economic growth and energy consumption causal nexus viewed through a bootstrap rolling window. Energy Economics, 32, 1398-1410.

Baur, D.G., (2012). Financial contagion and the real economy. Journal OfBanking \& Finance, 36, 2680-2692.

Bekiros, D.S. (2014). Contagion, decoupling and the spillover effects of the US financial crisis: evidence from the bric markets. International Review OfFinancial Analysis, 33, 58-69.

Buberkoku, Ö \& Kizildere, C. (2018). Has the turkish economy experienced a contagion effect from the global financial crisis?. Journal of Business Research-Turk 10(4) 1272-1297.

Celik, S. (2012). The more contagion effect on emerging markets: the evidence of dcc-garch model. Economic Modelling, 29, 1946-1959.

Chancharoenchai, K. \& Dibooglu, S. (2006). Volatility spillovers and contagion during the asian crisis: evidence from six southeast asian stock markets. Emerging Markets Finance and Trade, 42, 4-17. doi: 10.2753/REE1540-496X420201.

Dickey, D.A., Fuller, W.A., (1979). Distribution of the estimators for autoregressive time series with a unit root. Journal of the American Statistical Society, 75, 427-431.

Dimitriou, D., Kenourgios, D., Simos,T., (2013). Global financial crisis and emerging stock market contagion: a multivariate fiaparch-dcc approach. International Review of Financial Analysis, 30, 46-56.

Enders, W., Lee, J., (2012). The flexible fourier form and dickey-fuller type unit root tests. Economics Letters, 117, 196199.

Enders, W., \& Jones, P. (2016). Grain prices, oil prices, and multiple smooth breaks in a VAR. Studies in Nonlinear Dynamics \& Econometrics, 20(4), 399-419.
Engle, R. F., and Granger, C. W. J. (1987). Co-integration and error correction: representation, estimation and testing. Econometrica, 55, 251-276.

Forbes, K. J., Rigobon, R. (2002). No contagion, only interdependence: measuring stock market comovements. Journal of Finance, 57(5): 2223-2261.

Granger, C. W. (1969). Investigating causal relations by econometric models and cross-spectral methods. Econometrica: Journal of The Econometric Society, 424-438.

Gregory, A.W., Hansen, B., (1996a). Residual-based tests for cointegration in models with regime shifts. Journal of Econometrics, 70, 99-126.

Gregory, A. W., \& Hansen, B. E. (1996b). Practitioners corner: tests for cointegration in models with regime and trend shifts. Oxford Bulletin of Economics and Statistics, 58(3), 555560.

Gulzar, S., Mujtaba Kayani, G., Xiaofeng, H., Ayub, U., \& Rafique, A. (2019). Financial cointegration and spillover effect of global financial crisis: a study of emerging asian financial markets. Economic Research-Ekonomska Istraživanja, 32(1), 187-218.

Islam, Raisul, M. Talhatul Islam and A. Hannan Chowdhury; (2013). Testing for global volatility spillover, financial contagion and structural break in fifteen economies from two regions: a diagonal vech matrix and egarch $(1,1)$ approach. International Journal of Economics and Finance, 5(5), 159-170.

Kirac, F. \& Cicek, M. (2017). Mortgage krizinin uluslararası hisse senetleri piyasası üzerine bulaşma etkisi. Sosyal Bilimler Dergisi/Journal of Social Sciences, 1, Nisan, 75-97.

Kocabaş, C. (2016). 2008 krizinin bulaşma etkisi: bir finansal kriz göstergesi olarak hisse senedi fiyat endeksi üzerine bir analiz. Sosyal Arastirmalar ve Davranis Bilimleri Dergisi- Journal of Social Research and Behavioral Sciences, 2, Özel sayı, 1-23.

Nazlioglu, S., Gormus, N. A., \& Soytas, U. (2016). Oil prices and real estate investment trusts (reits): gradual-shift causality and volatility transmission analysis. Energy Economics, 60, 168-175.

Nazlioglu, S. (2019). GAUSS Time series and panel data tests package (tspdlib), https://github.com/aptech/tspdlib.

Pericoli, M. \& Sbracia, M. (2003). “A primer on financial contagion. Journal of Economic Surveys, 17(4), 571-608.

Perron, P. (1989). The great crash, the oil price shock, and the unit root hypothesis. Econometrica: Journal of the Econometric Society, 1361-1401.

Phillips, P. C., \& Ouliaris, S. (1990). Asymptotic properties of residual based tests for cointegration. Econometrica: Journal of the Econometric Society, 165-193.

Phillips, P. C. B., \& Perron, P. (1988). Testing for a unit root in time series regression. Biometrika, 75, 335-346. doi:10.2307/2336182

Polat, O. (2018). Hisse senedi piyasalarında finansal bağlantılılık analizi. PolitikEkonomik Kuram, Cilt:2, Sayi:1, ss.73-86. 
Rigobon, R. (2016). Staff Working Paper No. 607 Contagion, spillover and interdependence.

Roy, R. P., \& Roy, S. S. (2017). Financial contagion and volatility spillover: an exploration into indian commodity derivative market. Economic Modelling, 67, 368-380.

Samarakoon, L.P. (2011). Stock market interdependence, contagion, and the U.S. financial crisis: the case of emerging and frontier markets. Journal Of International Financial Markets, Institutions\&Money, 21, 724-742.

Toda, H. Y., \& Yamamoto, T. (1995). Statistical inference in vector autoregressions with possibly integrated processes. Journal of Econometrics, 66(1-2), 225-250.
Var, U. (2015). Türkiye ile Bazı Gelişmiş ve Gelişmekte Olan Ülkelerin Hisse Senedi Piyasaları Arasındaki Getiri ve Volatilite Yayılma İlişkisi ile Entegrasyonun Analizi (20092014). (Yayımlanmamış Yüksek Lisans Tezi). İstanbul Teknik Üniversitesi Fen Bilimleri Enstitüsü İşletme Mühendisliği Anabilim Dalı, İstanbul.

Ventosa-Santaulària, D., \& Vera-Valdés, J. E. (2008). Granger-causality in the presence of structural breaks. Economics Bulletin, 3(61).

Zivot, E., Andrews, W.K. (1992). Further evidence on the great crash, the oil-price shock, and the unit root hypothesis. Journal of Business and Economic Statistics 10(3), 251-270. 


\section{Appendix}

Table A1: Summary of Literature

\begin{tabular}{|c|c|c|c|}
\hline Reference & Countries & Method(s) & Finding \\
\hline $\begin{array}{l}\text { Gulzar et al. } \\
(2019)\end{array}$ & $\begin{array}{l}\text { India, China, } \\
\text { Pakistan, Malaysia, } \\
\text { Russia, Korea }\end{array}$ & $\begin{array}{l}\text { Johansen and } \\
\text { GARCH-BEKK }\end{array}$ & $\begin{array}{l}\text { Co-integration between US and } \\
\text { emerging markets is reported. }\end{array}$ \\
\hline $\begin{array}{l}\text { Altan \& } \\
\text { Yildirim (2019) }\end{array}$ & US, Turkey & ARDL Boundary Test & $\begin{array}{l}\text { Negative/Positive relationship in the } \\
\text { long/short terms between markets. }\end{array}$ \\
\hline $\begin{array}{l}\text { Akcali et al. } \\
(2019)\end{array}$ & Turkey & ARMA-EGARCH & $\begin{array}{l}\text { Contagion effects are valid between } \\
\text { variables of interest. }\end{array}$ \\
\hline Polat (2018) & G-7, Norway, Turkey & $\begin{array}{l}\text { VAR based on historical } \\
\text { volatility }\end{array}$ & $\begin{array}{l}\text { Highest financial risk transmission is } \\
\text { reported for US, followed by UK, and } \\
\text { lowest for Turkey. }\end{array}$ \\
\hline $\begin{array}{l}\text { Buberkoku \& } \\
\text { Kizildere (2018) }\end{array}$ & America, Turkey & $\begin{array}{l}A R(p)-D B E K K-G A R C H \\
A R(p)-S B E K K-G A R C H\end{array}$ & $\begin{array}{l}2008 \text { Crisis has impactedTurkey the } \\
\text { most. }\end{array}$ \\
\hline $\begin{array}{l}\text { Roy \& Sinha } \\
\text { Roy }(2017)\end{array}$ & India & DCC-MGARCH & $\begin{array}{l}\text { Financial contagion is highest with } \\
\text { stock market and lowest with gold } \\
\text { market for commodity derivatives. }\end{array}$ \\
\hline $\begin{array}{l}\text { Kirac \& Cicek } \\
(2017)\end{array}$ & 11 countries & DCC-GARCH & $\begin{array}{l}\text { Contagion effects are higher } \\
\text { especially in crisis period for } \\
\text { high-income countries. }\end{array}$ \\
\hline Kocabas (2016) & 25 countries & $\begin{array}{l}\text { ARCH-GARCH } \\
\text { MA (1)-GARCH }(1,1)-M\end{array}$ & $\begin{array}{l}\text { Countries which are highly } \\
\text { integrated with US financial } \\
\text { markets are more sensitive to crisis. } \\
\text { Evidence for contagion is reported. }\end{array}$ \\
\hline Bekiros (2014) & BRICS, US, Germany & $\begin{array}{l}\text { VAR and multiple } \\
\text { GARCH }\end{array}$ & $\begin{array}{l}\text { There are contagion effects in } \\
\text { BRICS markets following the } \\
\text { American financial crisis. }\end{array}$ \\
\hline Ayaydin (2014) & $\begin{array}{l}24 \text { developed and } \\
21 \text { emerging markets }\end{array}$ & Correlation analysis & $\begin{array}{l}\text { Financial contagion between } \\
\text { developed and emerging markets is } \\
\text { reported }\end{array}$ \\
\hline $\begin{array}{l}\text { Dimitriou et al. } \\
\text { (2013) }\end{array}$ & BRICS and America & $\begin{array}{l}\text { ARCH (FIAPARCH), } \\
\text { (DCC) }\end{array}$ & $\begin{array}{l}\text { Correlations have increased since } \\
\text { the beginning of } 2009 \text {. }\end{array}$ \\
\hline $\begin{array}{l}\text { Islam et al. } \\
(2013)\end{array}$ & 15 countries & $\begin{array}{l}\text { GARCH Diagonal VECH, } \\
\text { EGARCH }\end{array}$ & $\begin{array}{l}\text { Volatility spillover between } \\
\text { Asia-Pacific countries is more } \\
\text { dominant than international } \\
\text { contagion. }\end{array}$ \\
\hline Celik (2012) & 21 countries & DCC-GARCH & $\begin{array}{l}\text { Contagion is valid for most } \\
\text { countries. Higher contagion effects are } \\
\text { found for emerging markets. }\end{array}$ \\
\hline Baur (2012) & $\begin{array}{l}25 \text { developed and } \\
\text { developing countries, } \\
10 \text { sectors. }\end{array}$ & $\begin{array}{l}\text { Asymmetric } \\
\text { GJR-GARCH }\end{array}$ & $\begin{array}{l}\text { Health, telecommunications and } \\
\text { some sub-sectors in Tech. have been } \\
\text { affected the least from crisis. }\end{array}$ \\
\hline $\begin{array}{l}\text { Samarakoon } \\
(2011)\end{array}$ & 62 countries & Regression Estimation & $\begin{array}{l}\text { Source of contagion is shocks in } \\
\text { emerging markets. }\end{array}$ \\
\hline
\end{tabular}


Table A1: continued. Summary of Literature

\begin{tabular}{llll}
\hline Reference & Countries & Method(s) & Finding \\
\hline $\begin{array}{l}\text { Atakan et al. } \\
(2010)\end{array}$ & US, Turkey & $\begin{array}{l}\text { Granger Causality, IRF, } \\
\text { Variance Decomposition }\end{array}$ & $\begin{array}{l}\text { While impact of IMKB-100 on USD } \\
\text { increases, domestic interest rates } \\
\text { become less influential in crisis } \\
\text { period. }\end{array}$ \\
\hline $\begin{array}{l}\text { Chancharoenchai } \\
\text { \& Dibooglu } \\
(2006)\end{array}$ & $\begin{array}{l}\text { US, Japan, Thailand, } \\
\text { Philippines, Indonesia, } \\
\text { Malaysia, S. Korea, }\end{array}$ & GARCH-M & $\begin{array}{l}\text { Crisis has been spread to other } \\
\text { countries. This supports “Asian } \\
\text { contagion" idea. }\end{array}$ \\
\hline $\begin{array}{l}\text { Alper \& Yilmaz } \\
(2004)\end{array}$ & $\begin{array}{l}\text { US, UK, H.Kong, } \\
\text { Brazil, } \\
\text { S. Korea, Russia, }\end{array}$ & $\begin{array}{l}\text { Rolling regression } \\
\text { analysis, GARCH }\end{array}$ & $\begin{array}{l}\text { There is evidence for contagion } \\
\text { towards Turkey. }\end{array}$ \\
\hline
\end{tabular}


Table 1: Descriptive Statistics

\begin{tabular}{|c|c|c|c|c|c|c|c|}
\hline \multirow{2}{*}{$\begin{array}{l}\text { Panel A: } \\
\text { Price }\end{array}$} & XU100 & SPX & DAX & IBOV & RTSI & NIFTY & SHCOMP \\
\hline & & & \multicolumn{5}{|l|}{ Total Period } \\
\hline Mean & 52406.880 & 1563.960 & 7401.662 & 47261.34 & 1075.656 & 5092.581 & 2451.928 \\
\hline Std. Dev. & 30641.720 & 572.866 & 2851.090 & 23538.13 & 547.460 & 3175.956 & 886.380 \\
\hline Skewness & 0.143 & 0.978 & 0.448 & 0.104 & 0.078 & 0.414 & 0.881 \\
\hline Kurtosis & 1.849 & 2.899 & 2.127 & 2.380 & 2.266 & 2.107 & 4.186 \\
\hline$J-B$ & 303.618 & 828.079 & 337.539 & 92.443 & 121.446 & 319.851 & 974.243 \\
\hline \multirow[t]{2}{*}{ Prob. } & 0.000 & 0.000 & 0.000 & 0.000 & 0.000 & 0.000 & 0.000 \\
\hline & & & \multicolumn{5}{|l|}{ Pre-Crisis } \\
\hline Mean & 20002.07 & 1180.521 & 4986.300 & 21080.58 & 620.045 & 1790.860 & 1613.908 \\
\hline Std. Dev. & 11008.74 & 169.434 & 1353.512 & 9586.659 & 476.341 & 854.365 & 345.022 \\
\hline Skewness & 0.910 & -0.137 & 0.174 & 0.874 & 1.251 & 1.186 & 0.951 \\
\hline Kurtosis & 2.504 & 2.432 & 2.0529 & 2.668 & 3.492 & 3.380 & 4.551 \\
\hline$J-B$ & 276.087 & 30.787 & 79.027 & 245.838 & 504.461 & 447.985 & 467.182 \\
\hline \multirow[t]{2}{*}{ Prob. } & 0.000 & 0.000 & 0.000 & 0.000 & 0.000 & 0.000 & 0.000 \\
\hline & & & \multicolumn{5}{|l|}{ Post-Crisis } \\
\hline Mean & 70586.38 & 1779.074 & 8756.710 & 61949.07 & 1331.260 & 6944.887 & 2922.068 \\
\hline Std. Dev. & 21862.47 & 606.172 & 2559.734 & 14593.48 & 398.494 & 2405.835 & 737.971 \\
\hline Skewness & -0.059 & 0.406 & 0.129 & 1.045 & 0.518 & 0.430 & 1.398 \\
\hline Kurtosis & 2.421 & 2.054 & 1.756 & 4.056 & 2.873 & 2.096 & 5.683 \\
\hline J-B & 48.216 & 214.798 & 223.008 & 759.270 & 150.839 & 215.484 & 2077.775 \\
\hline Prob. & 0.000 & 0.000 & 0.000 & 0.000 & 0.000 & 0.000 & 0.000 \\
\hline \multicolumn{7}{|l|}{ Panel B: } & Total Period \\
\hline Mean & 0.0003 & 0.0002 & 0.0001 & 0.0004 & 0.0004 & 0.0004 & 0.0001 \\
\hline Std. Dev. & 0.020 & 0.012 & 0.014 & 0.017 & 0.021 & 0.014 & 0.015 \\
\hline Skewness & -0.061 & -0.225 & -0.057 & -0.108 & -0.442 & -0.295 & -0.359 \\
\hline Kurtosis & 11.501 & 12.036 & 7.856 & 7.283 & 12.502 & 12.923 & 8.490 \\
\hline $\mathrm{J}-\mathrm{B}$ & 15600.38 & 17667.49 & 5091.47 & 3969.76 & 19654.07 & 21325.56 & 6617.02 \\
\hline \multirow[t]{2}{*}{ Prob. } & 0.000 & 0.000 & 0.000 & 0.000 & 0.000 & 0.000 & 0.000 \\
\hline & & & \multicolumn{5}{|l|}{ Pre-Crisis } \\
\hline Mean & 0.0005 & 0.0000 & 0.0000 & 0.0006 & 0.0013 & 0.0005 & 0.0004 \\
\hline Std. Dev. & 0.026 & 0.011 & 0.016 & 0.018 & 0.021 & 0.015 & 0.013 \\
\hline Skewness & 0.017 & 0.122 & -0.087 & -0.198 & -0.551 & -0.779 & 0.570 \\
\hline Kurtosis & 9.432 & 5.910 & 6.011 & 4.107 & 6.294 & 8.998 & 8.585 \\
\hline$J-B$ & 3207.52 & 661.11 & 705.18 & 107.23 & 935.72 & 2977.78 & 2519.20 \\
\hline \multirow[t]{2}{*}{ Prob. } & 0.000 & 0.000 & 0.000 & 0.000 & 0.000 & 0.000 & 0.000 \\
\hline & & & \multicolumn{5}{|l|}{ Post-Crisis } \\
\hline Mean & 0.0003 & 0.0002 & 0.0002 & 0.0003 & -0.0001 & 0.0003 & 0.0000 \\
\hline Std. Dev. & 0.016 & 0.012 & 0.014 & 0.017 & 0.021 & 0.013 & 0.016 \\
\hline Skewness & -0.270 & -0.371 & -0.022 & -0.049 & -0.381 & 0.070 & -0.649 \\
\hline Kurtosis & 7.439 & 14.214 & 9.419 & 9.537 & 16.099 & 15.999 & 8.150 \\
\hline$J-B$ & 2765.58 & 17466.53 & 5698.02 & 5910.48 & 23807.27 & 23373.22 & 3900.75 \\
\hline Prob. & 0.000 & 0.000 & 0.000 & 0.000 & 0.000 & 0.000 & 0.000 \\
\hline
\end{tabular}

Notes: Total period is from 04.01.2000 to 12.11.2019 (5181 observations), pre-crisis period is from 04.01.2000 to 21.02.2007 (1862 observations), and post-crisis period is from 22.02.2007 to 12.11.2019 (3319 observations). 
Table 2: Correlation coefficients

\begin{tabular}{lllllll}
\hline Total Period & RXU100 & RSPX & RDAX & RIBOV & RRTSI & RNIFTY \\
\hline RXU100 & - & & & & & \\
RSPX & 0.2197 & - & & & & \\
RDAX & 0.3295 & 0.5933 & - & & & \\
RIBOV & 0.2637 & 0.5742 & 0.4437 & - & & \\
RRTSI & 0.3695 & 0.2891 & 0.4180 & 0.3251 & - & \\
RNIFTY & 0.2382 & 0.2054 & 0.3016 & 0.2279 & 0.3163 & - \\
RSHCOMP & 0.0825 & 0.0618 & 0.1017 & 0.1145 & 0.1346 & 0.1812 \\
Pre-crisis & & & & & & \\
\hline RXU100 & - & & & & & \\
RSPX & 0.0962 & - & & & & \\
RDAX & 0.1972 & 0.5747 & - & & & \\
RIBOV & 0.1925 & 0.4782 & 0.3730 & - & & \\
RRTSI & 0.2946 & 0.1763 & 0.2774 & 0.1968 & - & \\
RNIFTY & 0.1366 & 0.0703 & 0.1565 & 0.1277 & 0.2227 & \\
RSHCOMP & 0.0271 & -0.0062 & -0.0087 & 0.0293 & 0.0014 & 0.0478 \\
Post-crisis & & & & & & \\
\hline RXU100 & - & & & & & \\
RSPX & 0.3430 & - & & & & \\
RDAX & 0.4854 & 0.6121 & - & & & \\
RIBOV & 0.3476 & 0.6290 & 0.4944 & - & & \\
RRTSI & 0.4629 & 0.3479 & 0.5139 & 0.4021 & - & \\
RNIFTY & 0.3531 & 0.2827 & 0.4076 & 0.2940 & 0.3751 & - \\
RSHCOMP & 0.1342 & 0.0908 & 0.1646 & 0.1579 & 0.1975 & \\
\hline & & & & & \\
\hline
\end{tabular}

Table 3: Results from unit root tests

\begin{tabular}{|c|c|c|c|c|c|c|c|c|c|c|}
\hline \multirow[b]{2}{*}{ Constant } & \multicolumn{5}{|c|}{ Level (log-prices) } & \multicolumn{5}{|c|}{ First- Difference (Return) } \\
\hline & ADF & ZA-ADF & TB & F-ADF & $f$ & ADF & ZA-ADF & TB & F-ADF & $f$ \\
\hline XU100 & -0.893 & $-4.661^{*}$ & 09/05/2003 & -1.211 & 3 & $-71.679 * * *$ & $-71.789 * * *$ & $06 / 24 / 2002$ & $-71.711^{* * *}$ & 3 \\
\hline SPX & -0.01 & -3.692 & $10 / 30 / 2007$ & -0.425 & 3 & $-55.531^{* * *}$ & $-55.724 * * *$ & 03/05/2009 & $-55.597^{* * *}$ & 3 \\
\hline DAX & -0.768 & -3.54 & $03 / 18 / 2002$ & -1.046 & 3 & $-73.215^{* * *}$ & $-52.389 * * *$ & 03/10/2003 & $-73.261^{* * *}$ & 3 \\
\hline IBOV & -0.878 & -3.609 & $08 / 05 / 2003$ & -1.525 & 2 & $-72.242^{* * *}$ & $-72.295^{* * *}$ & $10 / 14 / 2002$ & $-72.262^{* * *}$ & 3 \\
\hline RTSI & -2.218 & -2.962 & $04 / 03 / 2003$ & -2.616 & 3 & $-66.005^{* * *}$ & $-66.108^{* * *}$ & $05 / 15 / 2008$ & $-66.046^{* * *}$ & 1 \\
\hline NIFTY & -0.456 & -4.272 & $06 / 22 / 2004$ & -0.698 & 2 & $-68.058^{* * *}$ & $-68.094^{* * *}$ & $04 / 23 / 2003$ & $-68.095^{* * *}$ & 2 \\
\hline SHCOMP & -1.749 & -3.428 & 03/09/2006 & -2.505 & 2 & $-29.392^{* * *}$ & $-33.892^{* * *}$ & $10 / 12 / 2007$ & $-29.478^{* * * *}$ & 3 \\
\hline \multicolumn{11}{|c|}{ Constant \& trend } \\
\hline XU100 & $-2.652^{*}$ & $-4.602^{*}$ & $07 / 29 / 2003$ & $-3.844^{* *}$ & 1 & $-71.672^{* * *}$ & $-71.815^{* * *}$ & $02 / 23 / 2003$ & $-71.705^{* * *}$ & 3 \\
\hline SPX & -2.173 & -4.514 & 06/04/2008 & -2.328 & 3 & $-55.563^{* * *}$ & $-55.719 * * *$ & 03/05/2009 & $-55.608^{* * *}$ & 3 \\
\hline DAX & $-2.738^{*}$ & -4.369 & $03 / 11 / 2003$ & -3.05 & 3 & $-73.223^{* * *}$ & $-52.476^{* * *}$ & 03/10/2003 & $-73.259^{* * *}$ & 3 \\
\hline IBOV & -1.896 & -3.754 & $02 / 25 / 2003$ & -3.176 & 1 & $-72.235^{* * *}$ & $-72.311^{* * *}$ & $10 / 14 / 2002$ & $-72.281^{* * *}$ & 1 \\
\hline RTSI & -1.895 & -4.023 & $06 / 18 / 2008$ & -3.309 & 1 & $-66.018^{* * *}$ & $-66.103^{* * *}$ & $05 / 15 / 2008$ & $-66.041^{* * *}$ & 1 \\
\hline NIFTY & -2.488 & -4.307 & 05/09/2003 & -3.474 & 1 & $-68.053^{* * *}$ & $-68.134^{* * *}$ & $04 / 23 / 2003$ & $-68.088^{* * *}$ & 2 \\
\hline SHCOMP & -1.892 & -3.879 & 03/09/2006 & -2.12 & 3 & $-29.392^{* * *}$ & $-33.940^{* * * *}$ & 10/12/2007 & $-29.476^{* * *}$ & 3 \\
\hline
\end{tabular}

Notes: Schwarz criterion was used to select the optimal lag from maximum 12 lags. The Fourier frequency was determined by minimizing residuals sum of squares. The critical values are $-3.433(1 \%),-2.862(5 \%),-2.567$ (10\%) for ADF; $-5.34(1 \%),-4.80$ (5\%), $-4.58(10 \%)$ for ZA-ADF; and -4.31 (1\%), $-3.75(5 \%),-3.45$ (10\%) for F-ADF. * $(10 \%)$, ${ }^{* *}(5 \%)$, and *** (1\%). 
Table 4: Results from cointegration tests without structural breaks

\begin{tabular}{|c|c|c|c|c|c|c|c|c|c|c|c|c|}
\hline \multirow{3}{*}{$\begin{array}{l}\text { Constant } \\
A D F\end{array}$} & \multicolumn{2}{|l|}{ SPX } & \multicolumn{2}{|l|}{ DAX } & \multicolumn{2}{|l|}{ IBOV } & \multicolumn{2}{|l|}{ RTSI } & \multicolumn{2}{|l|}{ NIFTY } & \multicolumn{2}{|l|}{ SHCOMP } \\
\hline & \multicolumn{12}{|c|}{ Panel A: Total Period } \\
\hline & -2.185 & & -2.919 & & -2.137 & & -0.652 & & -3.977 & $* * *$ & -1.280 & \\
\hline$Z_{t}$ & -2.078 & & -2.804 & & -1.903 & & -0.662 & & -3.655 & $* *$ & -1.239 & \\
\hline$Z_{\alpha}$ & -7.669 & & -13.619 & & -7.891 & & -1.521 & & -27.686 & $* *$ & -4.036 & \\
\hline \multicolumn{13}{|c|}{ Constant and trend } \\
\hline$A D F$ & -3.941 & $* *$ & -4.134 & $* *$ & -3.926 & $* *$ & -3.990 & $* *$ & -4.187 & $* *$ & -4.061 & $* *$ \\
\hline$Z_{t}$ & -3.896 & $* *$ & -4.136 & $* *$ & -3.844 & $* *$ & -4.008 & $* *$ & -4.000 & $* *$ & -4.054 & ** \\
\hline$Z_{\alpha}$ & -29.855 & $* *$ & -33.933 & $* *$ & -27.777 & $* *$ & -29.388 & $* *$ & -32.117 & $* *$ & -30.545 & ** \\
\hline Constant & \multicolumn{12}{|c|}{ Panel B:Pre-crisis } \\
\hline$A D F$ & -0.792 & & -0.103 & & -3.414 & $* *$ & -2.315 & & -3.072 & * & 1.272 & \\
\hline$Z_{t}$ & -0.634 & & -0.03 & & -3.278 & $*$ & -2.167 & & -2.984 & & 1.311 & \\
\hline$Z_{\alpha}$ & -1.272 & & -0.05 & & -22.035 & $* *$ & -8.508 & & -19.043 & * & 2.430 & \\
\hline \multicolumn{13}{|c|}{ Constant and trend } \\
\hline$A D F$ & -3.603 & & -4.093 & $* *$ & -3.517 & & -2.372 & & -3.229 & & -2.591 & \\
\hline$Z_{t}$ & -3.501 & & -3.914 & $* *$ & -3.440 & & -2.230 & & -3.143 & & -2.591 & \\
\hline$Z_{\alpha}$ & -21.981 & & -25.293 & * & -23.094 & & -8.685 & & -20.448 & & -8.422 & \\
\hline Constant & \multicolumn{12}{|c|}{ Panel C: Post-crisis } \\
\hline$A D F$ & -2.932 & & -3.298 & * & -1.701 & & -1.353 & & -3.329 & * & -1.193 & \\
\hline$Z_{t}$ & -2.919 & & -3.245 & * & -1.585 & & -1.413 & & -3.082 & * & -1.184 & \\
\hline$Z_{\alpha}$ & -15.935 & & -20.009 & * & -4.794 & & -4.873 & & 19.271 & * & -3.169 & \\
\hline \multicolumn{13}{|c|}{ Constant and trend } \\
\hline$A D F$ & -3.227 & & -3.361 & & -3.158 & & -3.361 & & -3.377 & & -3.421 & \\
\hline$Z_{t}$ & -3.167 & & -3.374 & & -3.092 & & -3.402 & & -3.236 & & -3.397 & \\
\hline$Z_{\alpha}$ & -20.192 & & -22.759 & & -19.083 & & -23.473 & * & -21.104 & & -22.629 & \\
\hline
\end{tabular}

Notes: We use Schwarz information criterion for $A D F^{*}$ test with maximum 12 lag; and Bartlett with $4(\mathrm{~T} / 100) \wedge(2 / 9)$ for $Z_{t}^{*}$ and $Z_{\alpha}^{*}$ tests. The critical values for $A D F$ and $Z_{t}$ tests are $-3.962(1 \%),-3.365(5 \%),-3.066(10 \%)$ for the constant model and $-4.363(1 \%),-3.800(5 \%),-3.518$ $(10 \%)$ for the constant and trend model. The critical values for $Z_{\alpha}$ test are $-28.322(1 \%),-20.494(5 \%),-17.039(10 \%)$ for the constant model and $-35.419(1 \%),-27.087(5 \%),-23.192(10 \%)$ for the constant and trend model. ${ }^{*}(10 \%),{ }^{* *}(5 \%)$, and ${ }^{* * *}(1 \%)$.

Table 5: Results from cointegration tests with structural breaks

\begin{tabular}{|c|c|c|c|c|c|c|c|c|c|c|}
\hline Level shift & SPX & & DAX & & IBOV & & RTSI & NIFTY & & SHCOMP \\
\hline$A D F^{*}$ & -3.659 & & -4.236 & & -4.250 & & -3.547 & -4.717 & $* *$ & -2.998 \\
\hline$Z_{t}^{*}$ & -3.505 & & -4.114 & & -4.127 & & -3.577 & -4.473 & $*$ & -2.936 \\
\hline$Z_{\alpha}^{*}$ & -24.199 & & -33.859 & & -35.986 & & -25.726 & -40.291 & * & -18.628 \\
\hline \multicolumn{11}{|c|}{ Regime shift } \\
\hline$A D F^{*}$ & -4.057 & & -4.029 & & -4.679 & & -3.582 & -5.308 & $* *$ & -3.079 \\
\hline$Z_{t}^{*}$ & -3.827 & & -3.934 & & -4.609 & & -3.590 & -5.009 & $* *$ & -2.996 \\
\hline$Z_{\alpha}^{*}$ & -28.122 & & -30.831 & & -42.604 & * & -28.722 & -49.892 & $* *$ & -19.348 \\
\hline \multicolumn{11}{|c|}{ Regime and trend shift } \\
\hline$A D F^{*}$ & -5.283 & * & -5.345 & * & -5.039 & & -4.966 & -5.299 & * & -4.727 \\
\hline$Z_{t}^{*}$ & -5.291 & * & -5.264 & * & -4.682 & & -4.868 & -5.007 & & -4.600 \\
\hline$Z_{\alpha}^{*}$ & -28.122 & & -30.831 & & -42.604 & & -28.722 & -49.892 & & -19.348 \\
\hline
\end{tabular}

Notes: $A D F^{*}, Z_{t}^{*}$, and $Z_{\alpha}^{*}$ are Gregory and Hansen (1996a, 1996b) co-integration tests with a break. We use Schwarz information criterion for $A D F^{*}$ test with maximum 12 lag; and Bartlett kernel with the bandwidth $4(\mathrm{~T} / 100) \wedge(2 / 9)$ for $Z_{t}^{*}$ and $Z_{\alpha}^{*}$ tests. The critical values for $A D F^{*}$ and $Z_{t}^{*}$ tests are $-5.130(1 \%),-4.610(5 \%),-4.340(10 \%)$ for the level shift model; $-5.470(1 \%),-4.950(5 \%),-4.680(10 \%)$ for the regime shift model; and $-6.020(1 \%),-5.500(5 \%),-5.240(10 \%)$ for the regime and trend shift model. The critical values for $Z_{\alpha}^{*}$ test are $-50.070(1 \%)$, $-40.480(5 \%),-36.190(10 \%)$ for the level shift model; $-57.170(1 \%),-47.040(5 \%),-41.850(10 \%)$ for the regime shift model; and $-69.370(1 \%)$, $-58.580(5 \%),-53.310(10 \%)$ for the regime and trend shift model. * $(10 \%),{ }^{* *}(5 \%)$, and *** $(1 \%)$. 
Table 6: Results from Toda \& Yamamoto causality test

\begin{tabular}{|c|c|c|c|c|c|c|}
\hline \multicolumn{2}{|c|}{ Panel A: Total Period } & \multirow{2}{*}{$\frac{\operatorname{Lag}(p)}{2}$} & \multicolumn{2}{|l|}{ Wald } & \multirow{2}{*}{$\frac{p \text {-value }}{0.000}$} & \multirow{2}{*}{$\begin{array}{c}p \text {-value } \\
0.000\end{array}$} \\
\hline SPX & $\neq>$ XU100 & & 172.444 & $* * *$ & & \\
\hline DAX & $\not>>X U 100$ & 1 & 22.362 & $* * *$ & 0.000 & 0.000 \\
\hline IBOV & $\neq>$ XU100 & 2 & 151.087 & $* * *$ & 0.000 & 0.000 \\
\hline RTSI & $\not>>X U 100$ & 2 & 3.955 & & 0.138 & 0.141 \\
\hline NIFTY & $\not>>X U 100$ & 1 & 9.682 & $* * *$ & 0.002 & 0.001 \\
\hline SHCOMP & $\neq>X U 100$ & 1 & 2.646 & * & 0.104 & 0.095 \\
\hline XU100 & $\not>$ SPX & 2 & 0.169 & & 0.919 & 0.923 \\
\hline XU100 & $\neq>\mathrm{DAX}$ & 1 & 0.129 & & 0.719 & 0.721 \\
\hline XU100 & $\neq>\mathrm{IBOV}$ & 2 & 5.364 & * & 0.068 & 0.070 \\
\hline XU100 & $\neq>$ RTSI & 2 & 4.328 & & 0.115 & 0.117 \\
\hline XU100 & $\not>$ NIFTY & 1 & 11.636 & $* * *$ & 0.001 & 0.000 \\
\hline XU100 & $\neq>$ SHCOMP & 1 & 30.064 & $* * *$ & 0.000 & 0.000 \\
\hline \multicolumn{7}{|c|}{ Panel B:Pre-crisis } \\
\hline SPX & $\neq>$ XU100 & 2 & 66.968 & $* * *$ & 0.000 & 0.000 \\
\hline DAX & $\neq>$ XU100 & 1 & 9.288 & $* * *$ & 0.002 & 0.001 \\
\hline IBOV & $\neq>X U 100$ & 2 & 60.868 & $* * *$ & 0.000 & 0.000 \\
\hline RTSI & $\neq>$ XU100 & 1 & 0.744 & & 0.388 & 0.399 \\
\hline NIFTY & $\neq>$ XU100 & 1 & 2.165 & & 0.141 & 0.14 \\
\hline SHCOMP & $\neq>X U 100$ & 1 & 1.494 & & 0.222 & 0.185 \\
\hline XU100 & $\not>$ SPX & 2 & 0.473 & & 0.789 & 0.796 \\
\hline XU100 & $\neq>\mathrm{DAX}$ & 1 & 0.015 & & 0.901 & 0.893 \\
\hline XU100 & $\neq>\mathrm{IBOV}$ & 2 & 2.610 & & 0.271 & 0.286 \\
\hline XU100 & $\neq>$ RTSI & 1 & 0.714 & & 0.398 & 0.394 \\
\hline XU100 & $\not>$ NIFTY & 1 & 0.882 & & 0.348 & 0.347 \\
\hline XU100 & $\neq>$ SHCOMP & 1 & 3.951 & $* *$ & 0.047 & 0.051 \\
\hline \multicolumn{7}{|c|}{ Panel C: Post-crisis } \\
\hline SPX & $\neq>$ XU100 & 2 & 129.862 & $* * *$ & 0.000 & 0.000 \\
\hline DAX & $\neq>$ XU100 & 1 & 11.939 & $* * *$ & 0.001 & 0.000 \\
\hline IBOV & $\neq>X U 100$ & 2 & 99.145 & $* * *$ & 0.000 & 0.000 \\
\hline RTSI & $\neq>$ XU100 & 2 & 3.672 & & 0.159 & 0.166 \\
\hline NIFTY & $\neq>$ XU100 & 2 & 14.463 & $* * *$ & 0.001 & 0.000 \\
\hline SHCOMP & $\not>X U 100$ & 2 & 1.856 & & 0.395 & 0.360 \\
\hline XU100 & $\not>S P X$ & 2 & 0.255 & & 0.880 & 0.890 \\
\hline XU100 & $\neq>\mathrm{DAX}$ & 1 & 1.199 & & 0.273 & 0.258 \\
\hline XU100 & $\neq>\mathrm{IBOV}$ & 2 & 2.525 & & 0.283 & 0.283 \\
\hline XU100 & $\neq>\mathrm{RTSI}$ & 2 & 3.327 & & 0.190 & 0.185 \\
\hline XU100 & $\not>$ NIFTY & 2 & 35.808 & $* * *$ & 0.000 & 0.000 \\
\hline XU100 & $\neq>$ SHCOMP & 2 & 40.983 & $* * *$ & 0.000 & 0.000 \\
\hline
\end{tabular}

Notes: $\neq>>$ represents Granger non-causality hypothesis. $p$-val $\left.\right|^{\text {a: }}$ Asymptotic $p$-value. $p$-val ${ }^{\mathrm{b}}$ : Bootstrap $\mathrm{p}$-value from 1,000 re-sampling. In $\operatorname{VAR}(p+d), p$ was selected by Schwarz criterion with maximum 12 lags and $d$ is equal to 1 . VAR models consists of Turkey's XU100 and a foreign index. . * $(10 \%),{ }^{* *}(5 \%)$, and ${ }^{* *}(1 \%)$. 
Table 7: Results from Toda \& Yamamoto causality test with smooth structural shifts

\begin{tabular}{llccrcc}
\hline & & Lag $(\mathrm{p})$ & Freq. $(\mathrm{k})$ & Wald & p-value $^{\text {a }}$ & $\mathrm{p}_{\text {-value }}$ \\
\hline SPX & $\neq>$ XU100 & 2 & 3 & $174.621 * * *$ & 0.000 & 0.000 \\
DAX & $\neq>$ XU100 & 1 & 3 & $22.009 * * *$ & 0.000 & 0.000 \\
IBOV & $\neq>$ XU100 & 2 & 3 & $155.311 * * *$ & 0.000 & 0.000 \\
RTSI & $\neq>$ XU100 & 2 & 3 & 4.386 & 0.112 & 0.105 \\
NIFTY & $\neq>$ XU100 & 1 & 3 & $10.898 * * *$ & 0.001 & 0.000 \\
SHCOMP & $\neq>$ XU100 & 2 & 3 & 3.092 & 0.213 & 0.182 \\
& & & & & & 0.997 \\
XU100 & $\neq>$ SPX & 2 & 3 & 0.006 & 0.785 & 0.999 \\
XU100 & $\neq>$ DAX & 1 & 3 & $5.498 *$ & 0.064 & 0.796 \\
XU100 & $\neq>$ IBOV & 2 & 3 & $4.907 *$ & 0.086 & 0.072 \\
XU100 & $\neq>$ RTSI & 2 & 3 & $12.350 * * *$ & 0.000 & 0.092 \\
XU100 & $\neq>$ NIFTY & 1 & 3 & $32.536 * * *$ & 0.000 & 0.001 \\
XU100 & $\neq>$ SHCOMP & 2 & 3 & & & 0.000 \\
\hline
\end{tabular}

Notes: $\neq>$ represents Granger non-causality hypothesis. $p$-val ${ }^{a}$ : Asymptotic $p$-value. $p$-val ${ }^{b}$ : Bootstrap $p$-value from 1,000 re-sampling. In $\operatorname{VAR}(p+d), p$ and $k$ were selected by Schwarz criterion with maximum 12 lags and 3 frequency and $d$ is equal to 1 . VAR models consists of Turkey's XU100 and a foreign index. ${ }^{*}(10 \%),{ }^{* *}(5 \%)$, and ${ }^{* * *}(1 \%)$. 